ENTREPRENEURSHIP AND SUSTAINABILITY ISSUES

ISSN 2345-0282 (online) http://jssidoi.org/jesi/

2020 Volume 8 Number 2 (December)

http://doi.org/10.9770/jesi.2020.8.2(32)
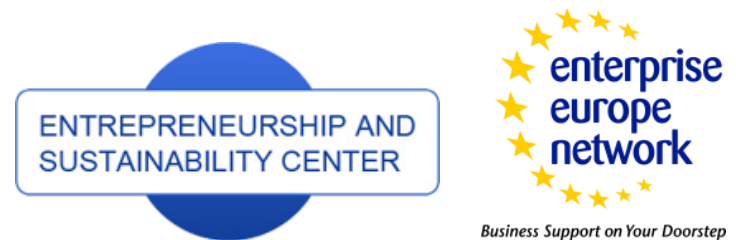

Business Support on Your Doorstep
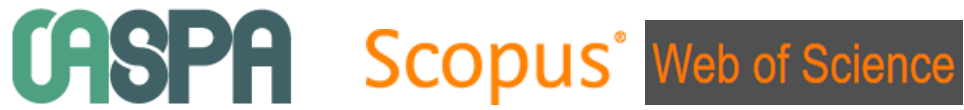

http://jssidoi.org/esc/home

\title{
Clarivate
Analytics \\ EU WASTE REGULATION IN THE CONTEXT OF THE CIRCULAR ECONOMY: PECULIARITIES OF INTERACTION
}

\author{
Andrius Stankevičius ${ }^{1}$, Andrejus Novikovas ${ }^{2}$, Audrius Bakaveckas ${ }^{3}$, Oleh Petryshyn ${ }^{4}$ \\ 1,2,3 Mykolas Romeris University, Ateities Str. 20, Vilnius, Lithuania \\ ${ }^{4}$ Yaroslav Mudryi National Law University, Pushkinskaya Str. 77, Kharkiv, \\ Ukraine \\ Emails: ${ }^{1}$ stankevicius@mruni.eu ; ${ }^{2}$ andrejus@mruni.eu ; ${ }^{3}$ audrius@mruni.eu $;{ }^{4}$ poe244@gmail.com
}

Received 10 August 2020; accepted 20 September 2020; published 30 December 2020

\begin{abstract}
The European Union (EU) is implementing the concept of the circular economy (hereafter - CE) system, the main idea of which is to maintain the added value in products for as long as possible both to improve the quality of the environment and eliminate waste. These provisions presuppose the improvement of EU waste management systems and legal regulation. The European Commission proposed a legislative package for amending the main Directives related to waste management. The European Parliament and the Council adopted this document in 2018. The legislative package amends six Directives, which are the main components of the legal framework for waste management in the EU. These are systematic changes in EU waste law regulation and include: the modification of the waste management system; the alignment of definitions; and the formulation of new legal definitions (for example municipal waste, backfilling) or establishment of qualitative and quantitative indicators which cover the meaning of waste hierarchy. The aim of this article is to divulge the main legal changes, and to evaluate their content in the context of the concept of the CE.
\end{abstract}

Keywords: circular economy; waste management; waste hierarchy; municipal waste; waste.

Reference to this paper should be made as follows: Stankevičius A, Novikovas A., Bakaveckas A., Petryshyn O. 2020 EU waste regulation in the context of the circular economy: peculiarities of interaction. Entrepreneurship and Sustainability Issues, 8(2), 533-545. http://doi.org/10.9770/jesi.2020.8.2(32)

JEL Classifications: Q01, Q5

Additional disciplines: law 


\section{ENTREPRENEURSHIP AND SUSTAINABILITY ISSUES}

ISSN 2345-0282 (online) http://jssidoi.org/jesi/

2020 Volume 8 Number 2 (December)

http://doi.org/10.9770/jesi.2020.8.2(32)

Make your research more visible, join the Twitter account of ENTREPRENEURSHIP AND SUSTAINABILITY ISSUES: @Entrepr69728810

\section{Introduction}

Over the last 5 years there has been an unprecedented speed of development in, on the one hand, such phenomena as Industry 4.0 and, on the other, the legal regulation of environmental protection. Today's economy, in the context of Industry 4.0, is based on digitization, technological development, big data, nanotechnology, and smart intelligence, and determines the development of industry activities whilst increasing consumption. The phenomena mentioned presuppose an increase in the use of natural resources and waste generation. The amount of waste generated and the disproportionate use of natural resources are factors that contribute to environmental degradation. The Treaty on the Functioning of the European Union (hereinafter - TFEU; Articles 11, 114, 191193) divulges certain objects of environmental protection: the quality of the environment, human health, natural resources, and climate change. We can also include city and country planning, water resources, and land use as, according to L. Kramer, "environment is not limited to natural elements, but also covers man-made environment" (2012, pp. 9-11). Waste management, as a systematic phenomenon, impacts environmental and social problems in a comprehensive manner.

Firstly, waste management (as a system) is a source of air, land, and water pollution. As an example, waste disposal activities include: depositing into or onto land, taking up land space and impacting the quality of air and soil; releasing waste into seas/oceans, impacting water quality; incineration on land or at sea, or variant physicalchemical or biological treatments, which may result in the emission of air pollutants. This means that waste management significantly affects the environment, and has serious impacts on the degradation of the whole ecosystem (Eurostat, 2019; Tvaronavičienè, 2016).

Secondly, the management of waste is related to climate change. According to the European Environment Agency's statistical data, air pollution and climate change are intertwined. Several air pollutants are also climate forcers, which have potential impacts on climate change and global warming in the short term (Limba, Novikovas, Stankevičius, Andrulevičius, \& Tvaronavičienè, 2020). For example, waste contributes a significant amount of $\mathrm{CH}_{4}$ emissions (European Environmental Agency, 2018).

Thirdly, waste management affects the utilization of natural resources and ensures the recovery of resources. According to Eurostat (2019), waste potentially represents an enormous loss of resources in the form of both materials and energy. Recycled materials are "secondary raw materials", which are injected back into the economy as new raw materials. Waste management practices have a direct impact on the quantity and quality of these materials (European Commission, 2015a).

Fourthly, the waste management sector impacts on market costs and the economic system. Pollution (for example of the air) determines both market costs and non-market costs. Market costs include reduced labour productivity, additional health expenditure, and losses in both crop and forest yields. Non-market costs are those associated with increased mortality and morbidity (causing illness, for example, and resulting in pain and suffering), the degradation of air and water quality and consequently the health of ecosystems, as well as climate change (European Environmental Agency, 2018). On the other hand, resource efficiency improvements could represent an overall savings potential of $€ 630$ billion per year for European industry and material cost saving opportunities for EU industry, boosting EU GDP by up to 3.9\% (European Commission, 2014).

Fifth, the waste management sector exists as a critical piece of infrastructure and forms part of the security phenomena. The waste management system interacts with economic, ecological, and national security issues (Novikovas \& Stankevičius 2018). 


\section{ENTREPRENEURSHIP AND SUSTAINABILITY ISSUES}

ISSN 2345-0282 (online) http://jssidoi.org/jesi/

2020 Volume 8 Number 2 (December)

http://doi.org/10.9770/jesi.2020.8.2(32)

Make your research more visible, join the Twitter account of ENTREPRENEURSHIP AND SUSTAINABILITY ISSUES: @Entrepr69728810

The implementation of the circular economy model at the EU level started in 2014-2015, emphasizing ideas of environmental protection and sustainable development. The concept of sustainable development was first introduced in 1987 in the report by United Nations World Commission on Environment and Development (1987) called Our Common Future as a "development that meets the needs of the present without compromising the ability of future generations to meet their own needs". According this report, sustainable development contains two key concepts: the concept of needs, in particular the essential needs of the world's poor, to which overriding priority should be given; and the idea of limitations imposed by the state of technology and social organization on the environment's ability to meet present and future needs. Research papers divulge the concept of sustainability into the triple bottom line (3BL), which encompasses three pillars of sustainability: economic, social, and environmental (Elkington, 1997). Environmental responsibility in the form of environmentally friendly and more efficient processes enables potential differentiation for businesses. Product and process innovations allow for additional benefits, including cost savings. From this point of view, environmental responsibility should be seen as a competitive advantage and not only as an inconvenient cost (Moumen, El Idrissi, Tvaronavičienè, \& Lahrach, 2019; Pechancová, Hrbáčková, Dvorský, Chromjaková, \& Stojanovicet, 2019).

The main idea of the Circular Economy Action Plan, (European Commission, 2015a) is to boost and create new jobs, for growth and investment, and to develop a carbon-neutral, resource-efficient, and competitive economy. It provides for a new approach to municipal waste management, a transition from the linear model "take, produce, throw away", to the circular economy model "waste prevention, eco-design, re-use, recycling and creating a circle market cycle" (Limba et al., 2020). The environmental protection concept, according to the CE phenomena, includes conventional consumer habits which "can also hinder new products and services development". Such barriers tend to persist in a context where prices do not reflect the real costs of resource use to society, and where policy fails to provide strong and consistent signals for the transition to a CE (European Commission, 2014). According to research papers, $\mathrm{CE}$ is understood as a system where the value is created by minimizing waste and the use of energy and natural resources (Tura et al., 2019). This is achieved by utilizing models for slowing, closing and narrowing loops of material and energy flows regeneratively, and following the principles of reduce, reuse, and recycle (Geissdoerfer, Savaget, Bocken, \& Hultinket, 2017; Langen \& Sornn-Friese, 2019; Sauvé, Bernard, \& Sloan, 2016).

\section{Methodology}

The aim of this article is to divulge the main legal changes in EU waste regulation and to evaluate the content of these changes in the context of the CE concept. The aim of the article will be realized through the following objectives:

- To reveal the theoretical framework of $\mathrm{CE}$ in the context of legal regulation;

- To assess systemic legal developments on the basis of the Proposal Package on waste management in the EU, according to the CE concept;

- To reveal basic legal categories of change on waste management

- To disclose the main characteristic of these legal changes.

The research is based on such methods as document analysis, statistical data analysis, historical, linguistic, logical, and systematic analysis. The data for this paper were gathered according to the key words (circular economy, waste management, waste hierarchy, municipal waste, and waste), using the methods of document analysis and statistical data. The authors relied on databases, such as those of Web of Science or Scopus, Eurostat, European Environmental Agency, the Court of Justice of the European Union (hereinafter - CJEU), and the Publications Office of the EU, which provide quality data and information for conducting research of this nature. 


\section{ENTREPRENEURSHIP AND SUSTAINABILITY ISSUES}

ISSN 2345-0282 (online) http://jssidoi.org/jesi/ 2020 Volume 8 Number 2 (December)

http://doi.org/10.9770/jesi.2020.8.2(32)

Make your research more visible, join the Twitter account of ENTREPRENEURSHIP AND SUSTAINABILITY ISSUES: @Entrepr69728810

The selected data, such as scientific literature, legal acts, and case-studies, were processed using content analysis. Using this method, the authors revealed legal categories related to the object of the topic. The linguistic (Latin lingua-language) method was used to reveal the meanings of the definitions by analysing the texts of scientific literature, the caselaw of CJEU, and legal documents. Using the historical method, the authors discussed the meaning of concepts such as waste, circular economy, and waste hierarchy throughout historical developments. A logical-systematic and linguistic analysis of the provisions of the legal acts related to the object of study, assessing them in the context of all other provisions of the legal regulation relevant to the dispute and taking into account the objectives pursued by the legal regulation, allowed for the reasonable formulation of conclusions.

\section{The analysis of the concept and package of documents of circular economy}

As mentioned above, the EU established a political commitment which enabled the transition from a linear model to a circular economy plan, outlining a new approach to waste management. It should be noted that this transition must be systematically analysed in the context of environment protection.

The European Parliament and the Council endorsed the 7th Environment Action Programme, in accordance with Articles 191-193 of the TFEU, which details European environmental policy (Decision No. 1386/2013). According to this document, waste management and the circular economy are identified as inter-related phenomena. For example, "prosperity and healthy environment stem from an innovative, circular economy where nothing is wasted and where natural resources are managed sustainably", or "barriers facing recycling activities in the Union internal market should be removed and existing prevention, re-use, recycling, recovery and landfill diversion targets reviewed so as to move towards a lifecycle-driven 'circular' economy, with a cascading use of resources and residual waste that is close to zero" (Decision No. 1386/2013).

The European Commission endorsed the Communications Towards a Circular Economy: A Zero Waste Programme for Europe (European Commission, 2014) and Closing the Loop - An EU Action Plan for the Circular Economy (European Commission, 2015a). As mentioned, the EU legal regulation does not establish an explicit definition of CE, but it reveals itself via the use of the systematic analysis method.

According to these documents, the long-term targets of the CE are: to reduce landfill; and to increase preparation for the reuse and recycling of key waste streams such as municipal waste and packaging waste. These provisions disclose the waste management system as a basic element of the $\mathrm{CE}$, and presuppose the evaluation of the practical realization of waste hierarchy. The concept of the $\mathrm{CE}$ envisages the establishment of imperative provisions in legal acts, such as qualitative and quantitative criteria (for example high-quality recycling or boosting the reuse and recycling of municipal waste to a minimum of $70 \%$ by 2030) or the simplification and harmonization of definitions. Other elements of the CE involve: designing and innovating; consumption; and functioning markets for secondary materials. Table 1 (below) reveals the content of the elements of the circular economy. 
ENTREPRENEURSHIP AND SUSTAINABILITY ISSUES

ISSN 2345-0282 (online) http://jssidoi.org/jesi/ 2020 Volume 8 Number 2 (December)

http://doi.org/10.9770/jesi.2020.8.2(32)

Make your research more visible, join the Twitter account of ENTREPRENEURSHIP AND SUSTAINABILITY ISSUES: @Entrepr69728810

Table 1. Elements of circular economy

\begin{tabular}{|c|c|}
\hline Production & $\begin{array}{l}\text { Designing } \\
\text { - Reducing the quantity of materials required to deliver a } \\
\text { particular service (lightweighting); } \\
\text { - Lengthening products' useful life (durability); } \\
\text { - Creating markets for secondary raw materials } \\
\text { (recyclates) based on standards, public procurement, etc. } \\
\text { Production processes } \\
\text { - Use of best available techniques for waste management; } \\
\text { - Implementation of the EU environmental management } \\
\text { and audit system; } \\
\text { - Promoting innovative industrial processes. }\end{array}$ \\
\hline Consumption & $\begin{array}{l}\text { - Green claims reliability, accuracy, and clarity for } \\
\text { preventing and reducing the generation of household } \\
\text { waste; } \\
\text { - Implementation of EU Ecolabel system; } \\
\text { - Ensuring methodology of Product Environmental } \\
\text { Footprint; } \\
\text { - Prevention of planned obsolescence practices. }\end{array}$ \\
\hline $\begin{array}{l}\text { Improving the EU legal framework for waste } \\
\text { management }\end{array}$ & $\begin{array}{l}\text { - Put into practice the EU waste hierarchy: prevention, } \\
\text { preparation for reuse, recycling, energy recovery, } \\
\text { disposal; } \\
\text { - } \\
\text { - Increase of the target for preparing for reuse and } \\
\text { recycling for municipal waste to } 65 \% \text { by } 2030 \text {; } \\
\text { - Gradual limitation of the landfill of municipal waste to } \\
10 \% \text { by } 2030 \text {; } \\
\text { - Greater harmonization and simplification of the legal } \\
\text { framework on by-products and end-of-waste status. }\end{array}$ \\
\hline Boosting the market for secondary raw materials & $\begin{array}{l}\text { - } \quad \text { Develop quality standards for secondary raw materials; } \\
\text { - } \quad \text { EU regulation on fertilisers; } \\
\text { - } \quad \text { Develop a Raw Materials Information System. }\end{array}$ \\
\hline
\end{tabular}

Source: compiled by authors based on European Commission $(2014 ; 2015 \mathrm{a})$

The European Commission endorsed Proposal for amending Directive 2008/98/EC on waste contains the proposed legislative package for amending the main Directives for waste management, not only Directive 2008/98/EC (European Commission, 2015b). The main objectives of this document (European Commission, 2015b) involve turning waste into a resource and closing the loop in a circular economy. The proposals, which form part of the CE Package, are aimed at addressing the legal obligation to review waste management targets in six different Waste Directives: Directive 2008/98/EC on waste; The Landfilling Directive (1999/31/EC); The Packaging Waste Directive (94/62/EC); The Directives on end-of-life vehicles (2000/53/EC); The Directive (2006/66/EC) on batteries and accumulators (and waste batteries and accumulators); and the Directive on waste electrical and electronic equipment (2012/19/EU). The proposed legislative package also envisages the improvement of targets of waste management, the alignment of definitions, the simplification and streamlining of reporting obligations, the establishment of qualitative and quantitative standards of waste management systems, and the greater harmonization and simplification of the legal framework on by-products and end-of-waste status. 
ENTREPRENEURSHIP AND SUSTAINABILITY ISSUES

ISSN 2345-0282 (online) http://jssidoi.org/jesi/

2020 Volume 8 Number 2 (December)

http://doi.org/10.9770/jesi.2020.8.2(32)

Make your research more visible, join the Twitter account of ENTREPRENEURSHIP AND SUSTAINABILITY ISSUES: @Entrepr69728810

In summary, the legal framework of CE phenomena in the field of waste management covers: TFEU Articles 191-193; the 7th Environment Action Programme; European environment policy (Decision No. 1386/2013); and European Commission communications (2014; 2015a; 2015b), which form part of a Circular Economy Package which includes the six Waste Directives mentioned above.

It is noteworthy that EU environmental law has been in development since the 1970s. Several hundred directives, regulations, and decisions are in force today in this field. Moreover, the effectiveness of EU environmental policy is largely determined not only by its implementation at the national, regional, and local levels, but also worldwide (European Commission, n.d.). The authors state that the CE document package includes the provisions of Agenda 2030. The CE action plan will be instrumental in reaching the Sustainable Development Goals (SDGs) by 2030, in particular Goal 12, i.e. ensuring sustainable consumption and production patterns (United Nations General Assembly's 2030 Agenda for Sustainable Development).

\section{EU waste regulation after amendments, according to the Proposal for Legislative Package (COM (2015) 595 final)}

As discussed above, the proposals are aimed at amending six Directives addressing the management of different wastes. The changes to the law documents mentioned are based on Articles 192(1) and 114 of the TFEU:

- Directive (EU) 2018/851 (hereinafter - D 2018/851) of the European Parliament and of the Council of 30 May 2018 amending Directive 2008/98/EC on waste (The Waste Framework Directive, hereinafter WFD 2008).

- Directive (EU) 2018/850 of the European Parliament and of the Council of 30 May 2018 amending Directive 1999/31/EC on the landfill of waste.

- Directive (EU) 2018/849 of the European Parliament and of the Council of 30 May 2018 amending Directives:

2000/53/EC on end-of-life vehicles,

2006/66/EC on batteries and accumulators and waste batteries and accumulators,

2012/19/EU on waste electrical and electronic equipment.

- Directive (EU) 2018/852 of the European Parliament and of the Council of 30 May 2018 amending Directive 94/62/EC on packaging and packaging waste.

The main objectives of these changes are to improve waste management in the EU, and thereby to contribute to the protection, preservation, and improvement of the quality of the environment, and to the prudent and rational utilisation of natural resources. A systematic assessment of the six Waste Directives to be amended presupposes the need to identify and analyse such basic features.

\subsection{Main targets of EU waste regulation}

The amended Article 1 of WFD 2008/98/EC, establishes a new provision and divulges the main targets of waste regulation. The subject matter and scope, according to Article 1, lays down measures to protect the environment and human health by preventing or reducing the generation of waste and the adverse impacts of the generation and management of waste, as well as by reducing the overall impacts of resource use and improving the efficiency of such use, both of which are crucial for the transition to a circular economy and for guaranteeing the EU's longterm competitiveness. The content of these provisions is disclosed through the systematic interpretation of other provisions of this document: Article 4 and Article 13. Article 4 reveals the content of waste hierarchy: as a priority order in waste prevention and management legislation and policy. Article 13 establishes the imperative to ensure that waste management is carried out without endangering human health, and without harming the 


\section{ENTREPRENEURSHIP AND SUSTAINABILITY ISSUES}

ISSN 2345-0282 (online) http://jssidoi.org/jesi/

2020 Volume 8 Number 2 (December)

http://doi.org/10.9770/jesi.2020.8.2(32)

Make your research more visible, join the Twitter account of ENTREPRENEURSHIP AND SUSTAINABILITY ISSUES: @Entrepr69728810

environment. The CJEU ruled that, whilst Article 13 does not specify the actual content of the measures which must be taken in order to ensure that waste is thus managed without endangering human health and without harming the environment, it is nonetheless true that the article is binding on the Member States as to the objective to be achieved, whilst leaving them a margin of discretion in assessing the need for such measures (Commission $v$. Slovenia, C-153/16). The objects of waste management systems mentioned above are established in all EU Waste Directives such that waste management in the Union should be improved with a view to: protecting, preserving, and improving the quality of the environment; protecting human health; ensuring the prudent, efficient, and rational utilisation of natural resources; and promoting the principles of the circular economy (Directive (EU) 2018/850, Directive (EU) 2018/849).

According to the above, EU waste management regulation includes economic factors (competitiveness, the circular economy, and qualitative standards) and environmental protection (environment, human health, and ensuring the prudent, efficient and rational utilisation of natural resources).

\subsection{The harmonization of definitions related to the concept of waste}

The circular economy document package emphasizes problematic aspects related to the content of definitions. The problems of definitions concern not only their content, but also involve the development of the waste management system. For example, to ensure the effectiveness of the concepts in practice, quality standards (secondary raw materials), cycles of processes (waste hierarchy), control mechanisms (quantitative and qualitative), and waste classification (hazardous/non-hazardous) are established.

To ensure simplification and the more effective implementation of EU legislation, CE documents propose:

a) to avoid overlaps amongst waste targets and calculation methods;

b) to implement harmonization of definitions (European Commission, 2014; 2015a).

Recitals 9 and 47 of Directive (EU) 2018/851 establish the alignment of the definitions in all Waste Directives and provide for new categories of definitions. Recital 9 specifies that the definitions of non-hazardous waste, municipal waste, construction and demolition waste, food waste, material recovery, backfilling, and extended producer responsibility schemes need to be included in Directive 2008/98/EC so that the scope of these concepts is clarified.

Article 3 of WFD 2008 reveals definitions related to waste management. Analysis of this provision leads to the conclusion that the harmonization of waste definitions will also include the replacement of existing norms. For example, in the definitions of bio-waste or waste management, the meaning of waste management is extended to include sorting activity.

Recitals of Directives D 2018/852 (amending Directive 94/62/EC on packaging and packaging waste) and D 2018/850 (amending Directive 1999/31/EC on the landfill of waste) highlighting WFD 2008 priority over other Waste Directives, as a legal category, solve the issue of alignment of the definitions: "in order to ensure greater coherence in Union waste law, the definitions in Directive 94/62/EC (or Directive 1999/31/EC) should be aligned, where relevant, with those of Directive 2008/98/EC of the European Parliament and of the Council which is applicable to waste in general". The provisions of amendments to Directive 1999/31/EC and Directive 94/62/EC establish a rule that the definitions of waste, waste management, collection, separate collection, prevention, reuse, treatment, recovery, recycling, disposal, and extended producer responsibility scheme laid down in Article 3 of WFD 2008 shall apply. 


\section{ENTREPRENEURSHIP AND SUSTAINABILITY ISSUES}

ISSN 2345-0282 (online) http://jssidoi.org/jesi/

2020 Volume 8 Number 2 (December)

http://doi.org/10.9770/jesi.2020.8.2(32)

Make your research more visible, join the Twitter account of ENTREPRENEURSHIP AND SUSTAINABILITY ISSUES: @Entrepr69728810

Although the WFD was endorsed in 2008, only 10 years later was a definition of municipal waste established. Municipal waste means: (a) mixed waste and separately collected waste from households, including paper and cardboard, glass, metals, plastics, bio-waste, wood, textiles, packaging, waste electrical and electronic equipment, waste batteries and accumulators, and bulky waste, including mattresses and furniture; or (b) mixed waste and separately collected waste from other sources, where such waste is similar in nature and composition to waste from households (WFD 2008). Thus the definition of waste management is revealed, emphasizing: a) the physical and chemical nature of waste (for example bulky waste is similar in nature and composition - i.e. is usually glass, wood, or textile); b) type of waste (mixed waste, bio-waste, bulky waste, waste batteries); c) source (waste from households or waste from other sources); and d) specific items (mattresses, furniture, batteries).

Researchers state that this definition is not accurate because it poses some theoretical questions. For example, what is the meaning of such a definition as bulky waste, mixed waste, furniture, or waste from other sources (WFD 2008)? The concept of municipal waste must be interpreted systematically within the concept of waste. It should be noted that the concept of waste has remained unchanged: waste means any substance or object which the holder discards or intends or is required to discard (WFD 2008). To reveal a clear meaning of waste is not simple. Firstly, it is necessary to assess what is not waste - cases that shall be excluded from the scope of WFD 2008 (Article 2). Secondly, to identify end-of-waste status (Article 6) or if a substance or object is considered not to be waste, but to be a by-product if the conditions mentioned in Article 5 are met.

The concept of waste is widely discussed among researchers and in the decisions of the CJEU. Some authors describe waste as objects that have an economic value, which may manifest in positive or negative aspects. L. Kramer states that "wastes are physical objects and as such are capable of being traded between Member States, and a buyer might have an interest in acquiring waste which has an economic value" (2012, pp. 76-77.). M. Grosz perceives "waste as a material or an assembly of materials with negative value" $(2011, \mathrm{p} .8)$. Others note that waste contains the same materials as are found in useful products; it only differs from useful production by its lack of value (White, Franke, \& Hidle, 1999).

Some authors highlight classification of criteria which divulge the concept of waste. Waste takes on various material forms and can feature any of the three classic aggregate phases: it may occur as a solid material, in liquid form, or even as a gaseous emission (Grosz, 2011). Sources of wastes are as follows: domestic wastes; commercial wastes; ashes; animal wastes; biomedical wastes; construction wastes; industrial solid wastes; sewers; biodegradable wastes; non-biodegradable wastes; and hazardous wastes (Demirbas, 2011). Authors on this topic additionally highlight such criteria as inert waste, processed waste, and unprocessed waste.

It should be noted that there exists another concept of waste - waste as an action. This requires a discussion on the content of waste based on the concept of discarding: the holder discards, or intends, or is required to discard an object (WFD 2008). This legal definition resembles the everyday understanding of waste - as something that we discard or throw away into the rubbish bin, using three alternatives: (1) which the holder discards; or (2) intends; or (3) is required to discard (Fisher, Lange, \& Scotford, 2019, p. 521). However, as mentioned, no definition of the term discard is given in the WFD 2008. This situation creates a broad definition of waste and a lack of clarity as to its precise meaning, which continues to provide difficulties in national implementation of the WFD 2008 and its subsequent daughter directives (Davies, 2017, pp. 226-228).

The CJEU, ruled to interpret the concept of waste widely, and the meaning waste is to be inferred primarily from the holder's actions and the meaning of the term discard (Openbaar Ministerie v. Tronex BV, Case C-624/17; Shell Nederland Verkoopmaatschappij BV and Belgian Shell NV, Case C-241/12). The term discard covers both 


\section{ENTREPRENEURSHIP AND SUSTAINABILITY ISSUES}

ISSN 2345-0282 (online) http://jssidoi.org/jesi/

2020 Volume 8 Number 2 (December)

http://doi.org/10.9770/jesi.2020.8.2(32)

Make your research more visible, join the Twitter account of ENTREPRENEURSHIP AND SUSTAINABILITY ISSUES: @Entrepr69728810

disposal and recovery of a substance or object (Inter-Environnement Wallonie ASBL v. Région wallonne, Case C129/96).

The Court also indicated that the existence of waste within the meaning of WFD 2008, must be determined in the light of all of the circumstances, and must be held to the aim of that directive and ensure that its effectiveness is not undermined. For example, an object or substance in question is not or is no longer of any use to its holder (constituting a burden and possessing the criterion to discard); or there is a degree of probability that goods, a substance, or a product will be reused without a prior processing operation (constituting a criterion to reuse, and not to discard; Commission v. Italy, Case C-263/05).

Based on the analysed data, the authors argue that the EU legal regulation develops the concept of definitions regarding the waste. It is possible to identify the classification of waste types and the systematic improvement (harmonization) of the content of definitions of waste. On the other hand, the concept of waste needs to be improved, which must meet the requirements of the waste hierarchy. Analysis of the CJEU judgments revealed a tendency whereby the meaning of the concept of waste is discussed in the context of waste hierarchy, for example the term discard manifesting in the stages of recovery or disposal. The authors agree with the provision that "the legal definition of waste overlooks the context of waste, fails to consider the interests of the waste user as opposed to the waste holder, and aims to control the impacts of careless discarding rather than stimulating careful discarding" (Ewijk \& Stegemann, 2020).

\subsection{Waste hierarchy}

The waste hierarchy establishes a priority order for prevention, preparation for reuse, recycling, and energy recovery through disposal, such as landfilling (European Commission, 2015a). Article 4 of WFD 2008 establishes the main elements (steps) of waste hierarchy: (a) prevention; (b) preparing for reuse; (c) recycling; (d) other recovery, e.g. energy recovery; and (e) disposal. According to Article 4 of Directive 2018/851, the following paragraph is added: "3. Member States shall make use of economic instruments and other measures to provide incentives for the application of the waste hierarchy, such as those indicated in Annex IVa or other appropriate instruments and measures". Annex IV divulges examples of economic instruments and other measures to provide incentives for the application of the waste hierarchy. These instruments include: charges and restrictions for using landfill and the incineration of waste, which incentivise waste prevention and recycling whilst keeping landfill the least preferred waste management option; fiscal incentives for the donation of products, in particular food; and the phasing out of subsidies which are not consistent with the waste hierarchy. Such measures are established in order to contribute to achieving the objectives laid down in Article 1 of the WFD 2008.

Waste hierarchy manifests as an obligatory imperative to Member States' waste management systems. Member states must undertake measures to prevent waste generation and ensure that waste undergoes preparation for reuse, recycling, or other recovery operations, and monitor and assess the implementation of waste prevention measures. For that purpose, they must use appropriate qualitative or quantitative indicators and targets, notably on the quantity of waste that is generated (WFD 2008).

The CJEU ruled that waste hierarchy must be revealed in the light of WFD 2008 Article 13: "Member States take the necessary measures to ensure that waste management is carried out without endangering human health and without harming the environment, in particular without risk to water, air, soil, plants or animals" ("Verdi Ambiente e Società - Aps Onlus" (VAS) and "Movimento Legge Rifiuti Zero per l'Economia Circolare" Aps v. Presidente del Consiglio dei Ministri and Others, Case C-305/18). In that regard, the Court has already ruled that, 


\section{ENTREPRENEURSHIP AND SUSTAINABILITY ISSUES}

ISSN 2345-0282 (online) http://jssidoi.org/jesi/

2020 Volume 8 Number 2 (December)

http://doi.org/10.9770/jesi.2020.8.2(32)

Make your research more visible, join the Twitter account of ENTREPRENEURSHIP AND SUSTAINABILITY ISSUES: @Entrepr69728810

whilst Article 13 does not specify the actual content of the measures which must be undertaken in order to ensure that waste is managed without endangering human health and without harming the environment, it is nonetheless true that that article is binding on the Member States as to the objective to be achieved, whilst leaving them a margin of discretion in assessing the need for such measures (Commission v. Slovenia, Case C-153/16).

Is the waste hierarchy mechanism enshrined in all of the Waste Directives? As mentioned above, the main target of the CE Documents Package is the alignment of definitions, and the greater harmonization and simplification of the legal framework of waste management. Recital 6 of Directive D 2018/849 (amending Directives 2000/53/EC, 2006/66/EC, 2012/19/EU) reveals: "The waste hierarchy laid down in WFD 2008 applies as an order of priority in the Union waste prevention and management legislation. When complying with the objectives of this Directive, Member States should take the necessary measures to take the order of priorities of the waste hierarchy into account and ensure the practical implementation of those priorities". Article 6 of Directive 2000/53/EC is amended as follows: "Member States shall take the necessary measures to ensure that all end-of-life vehicles are stored (even temporarily) and treated in accordance with the waste hierarchy and the general requirements laid down in Article 4 of WFD 2008". Article 22a, inserted into Directive 2006/66/EC, divulges incentives for the application of the waste hierarchy: "in order to contribute to the objectives laid down in this Directive, Member States may make use of economic instruments and other measures to provide incentives for the application of the waste hierarchy, such as those indicated in Annex IVa to the WFD 2008". The same principle is laid down in the provisions of Article 16a, inserted into amended Directive 2012/19/EU. The replaced article of Directive 94/62/EC on packaging and packaging waste stated that "In line with the waste hierarchy laid down in Article 4 of WFD 2008, Member States shall take measures to encourage the increase in the share of reusable packaging placed on the market and of systems to reuse packaging in an environmentally sound manner". With a view to supporting the Union's transition to a circular economy and meeting the requirements of WFD 2008 of the European Parliament and of the Council (1), and in particular Articles 4 and 12 thereof, the aim of this Directive is to ensure a progressive reduction in the landfilling of waste (Directive 1999/31/EC on the landfill of waste).

Based on the provisions mentioned, the authors argue that waste hierarchy, according to the CE documents package, is established as an imperative provision of EU waste regulation, including all key waste streams. This disclosure exists with the provision that waste hierarchy exists as Lex specialis (the doctrine states that if two laws govern the same factual situation, a law governing a specific subject matter (lex specialis) overrides a law governing only general matters (lex generalis). The content of imperative meaning consists of waste hierarchy stages, and the monitoring and assessment of qualitative or quantitative indicators and targets. Waste hierarchy manifests as a systematic phenomenon, which includes not only its obligatory nature, but also its status as an economic instrument to provide incentives for the application of the waste hierarchy.

\section{Conclusions}

The implementation of the circular economy concept of the EU had an important impact on the legal regulation of waste in the Union. Six directives have been amended: Waste Framework Directive 2008/98/EC; Directive 1999/31/EC on the landfill of waste; Directives 2000/53/EC on end-of-life vehicles; 2006/66/EC on batteries and accumulators and waste batteries and accumulators; 2012/19/EU on waste electrical and electronic equipment; and Directive 94/62/EC on packaging and packaging waste. The systematization of Waste Directives presupposes a conclusion that Waste Framework Directive 2008/98/EC discloses waste regulation as a fundamental Directive in the EU. The provisions of amended Waste Directives established references or priorities to Waste Framework Directive 2008/98/EC, interpreting the principles, definitions, or main targets of waste management. All disputes concerning the definition of the Directives should be guided by the Waste Framework Directive 2008/98/EC 


\section{ENTREPRENEURSHIP AND SUSTAINABILITY ISSUES}

ISSN 2345-0282 (online) http://jssidoi.org/jesi/ 2020 Volume 8 Number 2 (December)

http://doi.org/10.9770/jesi.2020.8.2(32)

Make your research more visible, join the Twitter account of ENTREPRENEURSHIP AND SUSTAINABILITY ISSUES: @Entrepr69728810

The authors conclude that the main elements of change in EU waste regulation must be the systematization of Waste Directives, the alignment and improvement of definitions related to the concept of waste, and ensuring the implementation of waste hierarchy and the targets of the waste management system. The waste hierarchy establishes a priority system within waste management, covering all types of waste. Waste hierarchy as legal imperative is established in all six amended Waste Directives, and manifests as a systematic phenomenon which includes imperative waste hierarchy stages, the monitoring and assessment of qualitative or quantitative indicators, and targets and economic instruments to provide incentives for the application of the waste hierarchy.

The new version of the Waste Framework Directive 2008/98/EC established new definitions (municipal waste) related to the concept of waste, as well as improving existing ones (waste management). It should be noted that the basic definition of waste remains unchanged. Analysis of the CJEU jurisprudence revealed arguments that waste definition exists as a problematic legal issue. The authors believe that the concept of waste needs to be improved in the light of the waste hierarchy, circular economy, and the CJEU jurisprudence. The authors conclude that the Directives should clearly and unambiguously define the concept of the circular economy.

\section{References}

"Associazione Verdi Ambiente e Società - Aps Onlus" (VAS) and "Movimento Legge Rifiuti Zero per l'Economia Circolare" Aps v. Presidente del Consiglio dei Ministri and Others, Case C-305/18 (CJEU 2019).

Commission v. Italy, Case C-263/05 (CJEU 2007).

Commission v. Slovenia, C-153/16 (CJEU 2017).

Decision No. 1386/2013/EU of the European Parliament and of the Council of 20 November 2013 on a General Union Environment Action Programme to 2020 'Living well, within the limits of our planet'. Official Journal of the European Union, L 354/171. Retrieved from https://eur-lex.europa.eu/legal-content/EN/TXT/PDF/?uri=CELEX:32013D1386\&from=EN

Directive (EU) 2018/851 of the European Parliament and of the Council of 30 May 2018 amending Directive 2008/98/EC on waste. Official Journal of the European Union, L 150, 109-140. Retrieved from https://eur-lex.europa.eu/legalcontent/EN/TXT/?uri=celex:32018L0851

Directive (EU) 2018/850 of the European Parliament and of the Council of 30 May 2018 amending Directive 1999/31/EC on the landfill of waste. Official Journal of the European Union, L 150/100. Retrieved from https://eur-lex.europa.eu/legalcontent/EN/TXT/PDF/?uri=CELEX:32018L0850\&from=lt

Directive (EU) 2018/849 of the European Parliament and of the Council of 30 May 2018 amending Directives: 2000/53/EC on end-of-life vehicles, 2006/66/EC on batteries and accumulators and waste batteries and accumulators, and 2012/19/EU on waste electrical and electronic equipment. Official Journal of the European Union, L 150/93. Retrieved from https://eur-lex.europa.eu/legalcontent/EN/TXT/PDF/?uri=CELEX:32018L0849\&from=LT

Directive (EU) 2018/852 of the European Parliament and of the Council of 30 May 2018 amending Directive 94/62/EC on packaging and packaging waste. Official Journal of the European Union, L 150, 141-154. Retrieved from https://eur-lex.europa.eu/legalcontent/lt/TXT/?uri=CELEX\%3A32018L0852

Demirbas, A. (2011). Waste management, waste resource facilities and waste conversion processes. Energy Conversion \& Management, 52(2), 1280-1282. https://doi.org/10.1016/j.enconman.2010.09.025

Davies, P. (2017). European Union environmental law: An introduction to key selected issues. New York: Routlege. 


\section{ENTREPRENEURSHIP AND SUSTAINABILITY ISSUES}

ISSN 2345-0282 (online) http://jssidoi.org/jesi/ 2020 Volume 8 Number 2 (December)

http://doi.org/10.9770/jesi.2020.8.2(32)

Make your research more visible, join the Twitter account of ENTREPRENEURSHIP AND SUSTAINABILITY ISSUES: @Entrepr69728810

Elkington, J. (1997). Cannibals with forks. The triple bottom line of 21st century. Hoboken, NJ: John Wiley \& Son.

Ewijk, S., \& Stegemann, J. A. (2020). Recognising waste use potential to achieve a circular economy. Waste Management, 105 , 1-7. https://doi.org/10.1016/j.wasman.2020.01.019

European Environmental Agency. (2018). Air quality in Europe - 2018 report (EEA Report No. 12/2018). Retrieved from https://www.eea.europa.eu/publications/air-quality-in-europe-2018

Eurostat. (2019). Energy, transport and environment statistics - 2019 edition. Luxembourg: Publications Office of the European Union. Retrieved from https://ec.europa.eu/eurostat/web/products-statistical-books/-/KS-DK-19-001

European Commission. (2014). Communication from the Commission to the European Parliament, the Council, the European Economic and Social Committee and the Committee of the Regions. Towards a circular economy: A zero waste programme for Europe. COM (2014) 0398 final. Retrieved from https://eur-lex.europa.eu/legal-content/EN/TXT/?uri=celex\%3A52014DC0398

European Commission. (2015a). Communication from the Commission to the European Parliament, the Council, the European Economic and Social Committee and the Committee of the Regions. Closing the loop - an EU action plan for the circular economy. COM (2015) 614 final. Retrieved from https://eur-lex.europa.eu/legal-content/EN/TXT/?uri=CELEX\%3A52015DC0614

European Commission. (2015b). Proposal for amending Directive 2008/98/EC on waste. COM (2015) 595 final - $2015 / 0275$ (COD). Retrieved from https://eur-lex.europa.eu/legal-content/EN/TXT/PDF/?uri=CELEX:52015PC0595\&from=EN

European Commission. (n.d.) Multilateral $\quad$ Environmental $\quad$ Agreements. Retrieved from https://ec.europa.eu/environment/international_issues/agreements_en.htm

Fisher, E., Lange, B., \& Scotford, E. (2019). Environmental law: Text, cases and materials (2nd ed.). Oxford: Oxford University Press.

Geissdoerfer, M., Savaget, P., Bocken, N., \& Hultink, E. (2017). The circular economy - a new sustainability paradigm? Journal of Cleaner Production, 143: 757-768, https://doi.org/10.1016/j.jclepro.2016.12.048

Grosz, M. (2011). Sustainable waste trade under WTO law: Chances and risks of the legal frameworks. Zurich: Hotei.

Inter-Environnement Wallonie ASBL v. Région wallonne, Case C-129/96 (CJEU 1997).

Kramer, L. (2012). EU environmental law (7th ed.). London: Thomson Reuters.

Langen, P., \& Sornn-Friese, H. (2019). Ports and the circular economy. In R. Bergqvist \& J. Monios (Eds.), Green ports: Inland and seaside sustainable transportation strategies (pp. 85-108). Elsevier. https://doi.org/10.1016/B978-0-12-814054-3.00005-0

Limba, T., Novikovas, A., Stankevičius, A., Andrulevičius, A., \& Tvaronavičienė, M. (2020). Big data manifestation in Municipal waste management and cryptocurrency sectors: Positive and negative implementation factors. Sustainability, 12(7), 2862. https://doi.org/10.3390/su12072862

Moumen, Z., El Idrissi, N. E. A., Tvaronavičienè, M., \& Lahrach, A. (2019). Water security and sustainable development. Insights into Regional Development, 1(4), 301-317. https://doi.org/10.9770/ird.2019.1.4(2)

Novikovas, A., \& Stankevičius, A. (2018). Municipal waste, as critical infrastructure, management: Case of Lithuania. Journal of Security and Sustainability Issues, 8(2), 257-265. https://doi.org/10.9770/jssi.2018.8.2(12)

Openbaar Ministerie v. Tronex BV, Case C-624/17 (CJEU 2019).

Pechancová, V., Hrbáčková, L., Dvorský, J., Chromjaková, F., \& Stojanovic, A. (2019). Environmental management systems: an effective tool of corporate sustainability. Entrepreneurship and Sustainability Issues, 7(2), 825841. http://doi.org/10.9770/jesi.2019.7.2(3)

Sauvé, S., Bernard, S., \& Sloan, P. (2016). Environmental sciences, sustainable development and circular economy: alternative concepts for transdisciplinary research. Environmental Development, 17, 48-56. https://doi.org/10.1016/j.envdev.2015.09.002 
ENTREPRENEURSHIP AND SUSTAINABILITY ISSUES

ISSN 2345-0282 (online) http://jssidoi.org/jesi/

2020 Volume 8 Number 2 (December)

http://doi.org/10.9770/jesi.2020.8.2(32)

Make your research more visible, join the Twitter account of ENTREPRENEURSHIP AND SUSTAINABILITY ISSUES: @Entrepr69728810

Shell Nederland Verkoopmaatschappij BV and Belgian Shell NV, Case C-241/12 (CJEU 2013).

Tura, N., Hanski, J., Ahola, T., Ståhle, M., Piiparinen, S., \& Valkokari, P. (2019). Unlocking circular business: A framework of barriers and drivers. Journal of Cleaner Production, 212, 90-98. https://doi.org/10.1016/j.jclepro.2018.11.202

Tvaronavičienè, M. (2016). Entrepreneurship and energy consumption patterns: case of households in selected countries. Entrepreneurship and Sustainability Issues, 4(1): 74-82. https://doi.org/10.9770/jesi.2016.4.1(1)

United Nations World Commission on Environment and Development. (1987). Report of the World Commission on Environment and Development: Our Common Future. Retrieved from https://sustainabledevelopment.un.org/content/documents/5987our-common-future.pdf

United Nations General Assembly, Transforming our world: the 2030 Agenda for Sustainable Development, 21 October 2015, A/RES/70/1. Retrieved from https://www.un.org/ga/search/view_doc.asp?symbol=A/RES/70/1\&Lang=E

White, R. P., Franke, M., \& Hindle, P. (1999). Integrated solid waste management: A lifecycle inventory. Berlin: Springer.

Andrejus NOVIKOVAS, Institute of Public Law at the Law School at Mykolas Romeris University. Research interests: administrative law, legislative process, public security.

ORCID ID: https://orcid.org/0000-0002-2715-1402

Audrius BAKAVECKAS, Institute of Public Law at the Law School at Mykolas Romeris University. Research interests: administrative law, legislative process.

ORCID ID: $\underline{\text { https://orcid.org/0000-0002-2840-1290 }}$

Andrius STANKEVIČIUS, Institute of Public Law at the Law School at Mykolas Romeris University. Research interests: public security, interest groups, lobbying, waste management, big data.

ORCID ID: https://orcid.org/0000-0002-2528-0497

Oleh PETRYSHYN, Department of the EU Law at Yaroslav Mudryi National Law University. Research interests: Ukraine's EU cooperation and integration policies, state-building, local self-government, and human rights.

ORCID ID: https://orcid.org/0000-0002-6099-8832

Copyright (C) 2020 by author(s) and VsI Entrepreneurship and Sustainability Center

This work is licensed under the Creative Commons Attribution International License (CC BY).

http://creativecommons.org/licenses/by/4.0/

(c) (i) Open Access 